\title{
P396: Balancing ventilation and energy use in hospitals: a case study of bioaerosol transport in healthcare environments
}

\author{
K Grosskopf
}

From 2nd International Conference on Prevention and Infection Control (ICPIC 2013)

Geneva, Switzerland. 25-28 June 2013

\section{Introduction}

Hospitals are among the most energy intensive buildings in industrialized countries, using more than two-thirds of total energy consumption to maintain climate control and indoor air quality (IAQ). Yet, hospital acquired infections (HAIs) afflict approximately $8 \%$ of the inpatient population and claim more than 115,000 lives each year in Europe and the U.S. alone.

\section{Methods}

A series of 4 tests were conducted in an actual hospital to observe removal rates and containment of synthetic bioaerosols with respect to air change rate, air pressure differential and door position in a general patient room, and, an isolation patient room.

\section{Results}

Air change rates were not found to be effective in proportionately reducing aerosol concentrations within patient rooms when the aerosol was continuously released. Specifically, increasing mechanical ventilation rates from 2.5 to 5.5 air changes per hour $(\mathrm{ACH})$ reduced aerosol concentrations only $30 \%$ on average. An air pressure differential of 2.5Pa, however, was found to be effective in containing aerosol transport from patient rooms to adjacent corridors except in cases where isolation anterooms were negatively pressurized with respect to isolation spaces. Door position and door motion was also found to have a significant effect on aerosol containment.

\section{Disclosure of interest}

None declared.

University of Nebraska, Lincoln, Nebraska, USA
Published: 20 June 2013

doi:10.1186/2047-2994-2-S1-P396

Cite this article as: Grosskopf: P396: Balancing ventilation and energy use in hospitals: a case study of bioaerosol transport in healthcare

environments. Antimicrobial Resistance and Infection Control 2013 2(Suppl 1): P396.
Submit your next manuscript to BioMed Central and take full advantage of:

- Convenient online submission

- Thorough peer review

- No space constraints or color figure charges

- Immediate publication on acceptance

- Inclusion in PubMed, CAS, Scopus and Google Scholar

- Research which is freely available for redistribution
() Biomed Central

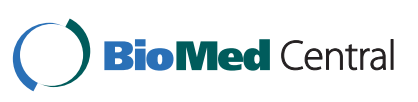

(c) 2013 Grosskopf; licensee BioMed Central Ltd. This is an Open Access article distributed under the terms of the Creative Commons Attribution License (http://creativecommons.org/licenses/by/2.0), which permits unrestricted use, distribution, and reproduction in any medium, provided the original work is properly cited. 